\title{
UK warns of cost short-fall over future space missions
}

London. The future involvement of the United Kingdom in the science missions of the European Space Agency (ESA) is being threatened by the fact that the increased cost of its subscription to the agency is undermining its ability to participate in individual space missions. Britain's difficulties could precipitate a full-scale review of the future of the European agency itself.

The warning comes from the newly formed Particle Physics and Astronomy Research Council (PPARC), which is keen to reduce the costs of its basic subscription to ESA - and, in the short term, to persuade the Office of Science and Technology to help it to accommodate current fluctuations in this cost.

Without additional short-term support (which could be made available when the science budget is allocated in December), PPARC has warned that British scientists may be forced to withdraw from participation in payload projects for ESA's next two missions, the gamma-ray observatory satellite INTEGRAL and the cometary probe Rosetta, both due for launch in 2001.

Britain's subscription to ESA has been rising because, although both the overall budget of the agency and that of the PPARC are nominally being kept level in 'real' terms, the former is being adjusted for a higher rate of inflation than the latter. One result is that the UK's subscription (like that to CERN, the European Laboratory for Particle Physics) is consuming an increasing proportion of PPARCS's budget. "It is like being elected a member of a golf club, but having nothing left to buy balls and a club after paying your subscription," says Ken Pounds, professor of physics at the University of Leicester and chief executive of the PPARC.

In last year's white paper on science funding, the government promised to explore ways in which responsibility for fluctuations in international subscriptions could be spread across the whole science budget. Pounds has already met Sir John Cadogan, the director-general of research councils, to discuss how this might be achieved.

At their next meeting, Pounds will take with him the conclusions of the PPARC council, agreed to last month after a review of its scientific programme, that the council "would be unable to participate significantly in the national development of instruments for future ESA space science missions without additional funds from Government".

According to Pounds, these conclusions apply in particular to the INTEGRAL and Rosetta missions. Britain's main involvement in the first of these is through the caesium iodide imager, one of the two main instruments to be carried on the satellite. As one of the four principal members of ESA the others are France, Germany and Italy Britain is hoping to play "a very significant role in both of these missions", says Pounds. "If we are not able to be involved, then it would send shock-waves through the European space programme."

\section{IMAGE UNAVAILABLE FOR COPYRIGHT REASONS}

\section{The Integral Mission: can Britain's astronomers still participate?}

Roger Bonnet, head of ESA's science programme, admits that the agency is "very concerned" at the conclusions of PPARC's council, and accepts that a British withdrawal from INTEGRAL and Rosetta would have wide implications. "It would be a tremendous setback," says Bonnet, adding that he is already exploring ways of avoiding such a move.

Bonnet points out that ESA came out well from a recent review of its cost-effectiveness. But he admits that there may be scope for improvement, adding that, if the United Kingdom feels there are new areas worth investigating for potential savings, he would certainly consider doing so.

According to Pounds, Britain is not the only ESA member to be facing difficulties caused by the increasing cost of the ESA subscription. The only difference, he says, is that government restrictions on the science budget have meant that Britain "hit the brick wall first".

"In the short term, it is essential that the government offers PPARC protection against the currency fluctuations in our subscription to ESA - and to CERN," says Pounds. "In the longer term, we must work, with our international partners, to reduce the cost of these major science programmes."

Several countries are believed to feel that the problems facing ESA do not lie in the administration of its science programmes, but in the heavy infrastructure built around its efforts to develop a European mannedspaceflight programme, whose main incentive has evaporated with the ending of the Cold War.
Maggie Verrall

\section{Darwin deal marks growth of link-ups for gene companies}

San Francisco. In the latest link-up between a large pharmaceutical company and a small genome-based biotechnology company, Rhône-Poulenc Rorer of France has signed a \$16.5-million agreement with Darwin Molecular Corporation, based in Seattle, Washington, to work on gene therapies for cancer.

The agreement combines Darwin's work on genes with the French company's vectors and gene-delivery technology, with the aim of targeting tumour cells. Darwin was established two years ago to convert information from the human genome into treatments for cancer, AIDS and autoimmune diseases.

Rhône-Poulenc will invest \$5 million in Darwin in exchange for about 10 per cent of its stock. It will provide the remaining $\$ 11.5$ million to Darwin over four years in the form of a second equity investment, research funding and milestone payments.

The deal follows several major investments by pharmaceutical companies in small genome companies. Last year, Human Genome Sciences Inc. of Rockville, Maryland, attracted \$125 million from SmithKline Beecham, and Millenium garnered $\$ 70$ million from Hoffman-La Roche. In June, Incyte, based in Palo Alto, California, reached a \$25-million agreement with Pfizer.

Darwin is believed to have been trying to set up a corporate collaboration for at least a year, with some observers claiming that the company has shown a lack of focus. But David Galas, acting chief executive of Darwin following the recent departure of Mark Pearson, says that the deal with RhônePoulenc Rorer is the first stage of what promises to be a larger commitment.

According to Galas, Darwin is in the early stages of talks with several companies about agreements on DNA sequencing, gene discovery and molecular evolution, a technology that uses environmental pressures to 'select' artificially new molecules with particular strengths.

Darwin and Rhône-Poulenc Rorer plan to develop a gene-therapy approach employing Darwin's novel herpes thymidine kinase genes to trigger the activity of the antiviral ganciclovir against tumour cells.

Rhône-Poulenc has said it aims to persuade biotechnology companies to work together in order to speed the development of new drugs and treatments, operating in a network similar to that of the software company Microsoft, whose founder William $\mathrm{H}$. Gates is a key investor and board member of Darwin. Darwin would eventually be part of a larger constellation of biotechnology and pharmaceutical companies working with Rhône-Poulenc (see Nature 369, 92; 1994).

Sally Lehrman 